\title{
Epiphyllous Lejeuneaceae in Costa Rica Contributions to the altitudinal distribution of selected species
}

\section{Jens Eggers}

\section{Blockhorner Weiden 3, D-22869 Schenefeld, Germany}

\begin{abstract}
The altitudinal distribution of selected species of epiphyllous Lejeuneaceae shows 6 groups (table 1 and 2): I (only lower than $500 \mathrm{~m}$ ) Cololejeunea setiloba; II (1-1600m) Aphanolejeunea costaricensis, A. moralesiae, Cololejeunea cardiocarpa, C. guadelupensis, C. linopteroides, C. obliqua, C. papillifera, C. standleyi, Colura verdoornii, Cyclolejeunea chitonia, C. peruviana, Diplasiolejeunea brunnea, Microlejeunea epiphylla, Rectolejeunea berteroana, R. cf. emarginuliflora, Stictolejeunea squamata; III (1-3000m) Aphanolejeunea angustissima, Colura tortifolia, Diplasiolejeunea cavifolia, D. pellucida, Drepanolejeunea inchoata, Dr. lichenicola, Lejeunea laetevirens, Odontolejeunea lunulata; IV (only 500-1600m) Aphanolejeunea cingens, A. longifolia, A. pustulosa, Cyclolejeunea accedens, C. convexistipa, Diplasiolejeunea grolleana, D. unidentata, Harpalejeunea uncinata, Lejeunea filipes, Odontolejeunea decemdentata; V (500-3000m) Anoplolejeunea conferta, Aphanolejeunea crenata, A. ephemeroides, Colura tenuicornis, Diplasiolejeunea alata, Drepanolejeunea infundibulata, Dr. mosenii, Lejeunea flava, Omphalanthus filiformis; VI (only above 1600-3000m) Aphanolejeunea camillii, Cololejeunea fefeana, Diplasiolejeunea costaricensis sp.nov., D. involuta.
\end{abstract}

\section{Introduction}

In his Hepaticae standleyana, part II Herzog (1951) listed several epiphyllous Lejeuneaceae from Costa Rica, but rarely with altitudinal dates. This lack did not change in later publications (e.g. Morales 1991). The dissertation of A. (Bernecker-)Lücking (1995) on material from the Braulio Carrillo National Park gave an idea of the richness of species in the area, which is situated at about $500 \mathrm{~m}$ on the Caribbean slope of the Cordillera Central. Afterwards Gradstein \& al. (1994) and Dauphin \& al. (1998) added several species new to Costa Rica which included some epiphyllous Lejeuneaceae too. In 1985 the author visited several places in various parts of Costa Rica and collected epiphyllous bryophytes; some were added in spring of this year (2001). The material mostly waited for determination until now (the author is greatly indebted to the mentioned dissertation of Bernecker-Lücking and the help of Dr. Tamas Pócs); the results may give a better impression of the altitudinal distribution of epiphyllous Lejeuneaceae in Costa Rica. The specimens are kept in the private Herbarium of Jens Eggers; duplicates of several species were sent to T. Pócs, J.-P.Frahm \& G.Schwab. 


\section{Localities}

The places mentioned in the tables 1 and 2 are not in arranged in a geographical order, but in altitudinal groups. Most of them are also listed in Morales (1991) together with their coordinates. The abbreviations used in the table for the provinces are the following: ALA = Alajuela, CAR $=$ Cartago, GUA $=$ Guanacaste, HER $=$ Heredia, JOS $=$ San José, LIM = Limon, PUN = Puntarenas. Collections by the author (Symbol: filled rhombus) are completed by those from literature (open circle). Records from Cocos Island are omitted.

\section{Altitudinal zonation}

The arrangement in the tables follows Gradstein $\&$ Frahm (in Frey 1987). Though the situation in NE-Peru is different from Costa Rica in many respects (e.g. higher mountains, closer to the equator) the model seems to be fit for giving an altitudinal order of the Costa Rican epiphyllous Lejeuneaceae too. The zones in Gradstein \& Frahm are: 1. „Tropische Tieflandstufe“ (Tropical Lowland Zone, 0-500m), 2. „Untere tropisch-montane Stufe" (Lower tropical montane Zone, 500-1900m), 3. „Obere tropischmontane Stufe" (Upper tropical montane Zone, 1900-3200) and 4. „Tropisch-alpine Stufe“ (Tropical alpine Zone, above 3200m). Zone 4 nearly doesn't occur in Costa Rica and there are no epiphyllous records. Gradstein \& Frahm divide the Zone 2 into a submontane (500$1300 \mathrm{~m})$ and a montane $(1300-1900 \mathrm{~m})$ part. This border is not obvious in the Costa Rican epiphyllous material. On the other hand Zone 3, which is also divided in Gradstein \& Frahm between $1900-2800 \mathrm{~m}$ and $2800-3200 \mathrm{~m}$, is distinctly poorer in Costa Rica already above $2000(2200) \mathrm{m}$. The species richness of the lowland zone is lower than that of the montane zones, but not so poor as in epiphyte bryophytes or those of other substrata.

The Caribbean and Pacific slopes of the Costa Rican Cordilleras differ mainly in humidity; there are considerable differences e.g. in the avian species composition. An arrangement of the Lejeuneaceae following the collecting places on the both slopes gave no new insights for interpretation beside the well known phenomenon of increasing humidity on the dry pacific side towards Panama. As far as humidity is constant and sufficient same species seem to occur on both slopes. The Pacific Lowland is therefore impoverished in epiphyllous hepatics.

\section{Species remarks}

From the gathered material most species were not taken into consideration which are collected only once, or those of genera not adequate determined (Ceratolejeunea, Taxilejeunea and other Lejeuneoideae).

Anoplolejeunea conferta (Meissn.) Evans is mentioned for La Palma without substratum by Herzog (1951).

Aphanolejeunea angustissima Steph. was mentioned as A. gracilis Jov.-Ast for Tapanti without altitude and substratum in Morales (1991) and reported as epiphyllous by (Bernecker-)Lücking for Braulio Carrillo NP. Aphanolejeunea camillii (Lehm.) Schust. (syn. A. misionensis Reiner). Leg. J.Eggers 1.2.1985 Prov. Heredia, between Montana and the Vulcan Barva, epiphyllous at $2000 \mathrm{~m}$ alt., det. T.Pócs (see also: Equihua \& Pócs 1999).

Aphanolejeunea cingens Herz. Reported by (Bernecker)-Lücking (1995 and in Gradstein \& al. 1994) for Braulio Carrillo NP.

Aphanolejeunea costaricensis BerneckerLücking. Described by (Bernecker-)Lücking from Braulio Carrillo NP $(1995,1998)$ and hitherto only known from there.

Aphanolejeunea crenata Evans is mentioned for Cerro de las Caricias without substratum by Herzog (1951), as epiphyllous for the Volcan Barva without altitude by Morales (1991) and one epiphyllous record for the Braulio Carrillo NP by (Bernecker-)Lücking (1995).

Aphanolejeunea ephemeroides Schust. Reported by (Bernecker-)Lücking (1995 and in Gradstein $\&$ al. 1994) for Braulio Carrillo NP.

Aphanolejeunea longifolia Jov.-Ast. Two epiphyllous records in the Braulio Carrillo NP are reported by (Bernecker-)Lücking (1995 and in Dauphin \& al. 1998).

Aphanolejeunea moralesiae Bernecker-Lücking. Described by Bernecker-Lücking from Braulio Carrillo NP $(1995,1998)$; she also reported the species from Rio Squirres in Prov. Limon, epiphyllous without altitude.

Aphanolejeunea pustulosa (Jov.-Ast) Bernecker 
\& Pócs. (see: New bryophyte taxon records ... IV, this volume).

Cololejeunea cardiocarpa (Mont.) Evans was mentioned for Turrialba, leg. C.Bayer, without altitude and substratum by Morales (1991).

Cololejeunea fefeana Tix. (see: New bryophyte taxon records ... IV, this volume).

Cololejeunea guadelupensis Tix. (see: New bryophyte taxon records ... IV, this volume).

Cololejeunea linopteroides Robins. Reported by Herzog (1951) as Cololejeunea aloba from Naranjos Agrios, epiphyllous, 600-700m, by Robinson (1964), by (Bernecker)-Lücking from Braulio Carrillo NP as Cololejeunea gradsteinii (1995) and by Bernecker-Lücking \& Morales (1999) as mostly epiphyllous from various locations without altitude.

Cololejeunea obliqua (Nees \& Mont.) Schiffn. was mentioned for many places without altitude and substratum by Herzog (1951) and Morales (1994), whereas the cited record of (the synonym) C. scabriflora Gott. by Reed \& Robinson (1971) was made by James 1965 on Citrus leaves lower than $1500 \mathrm{~m}$ in Monteverde. The species is only mentioned once in (Bernecker-)Lücking among her epiphyllous maeterial from Braulio Carrillo (1995).

Cololejeunea papillifera Schust. The species was described for Costa Rica by Herzog (1951) sub Cololejeunea minutiloba as epiphyllous without locality. It was found also 30.1.1985 by the author near Puerto Viejo, epiphyllous at 100m alt., conf. T.Pócs, and the same day at $850 \mathrm{~m}$ alt. above San Miguel de Saraquipi.

Cololejeunea setiloba Evans (see: New bryophyte taxon records ... IV, this volume).

Cololejeunea standleyi Herz. was recorded in the lowland forest of Carara by Döbbeler \& Dauphin without mentioning the substratum, where the author found it again in 2001. Earlier reports by Morales (1991) were based on misidentifications (Dauphin \& al. 1998).

Colura tenuicornis (Evans) Steph. was reported by Reed \& Robinson (1971) from Monteverde on Citrus leaves at lower than $1500 \mathrm{~m}$ alt. (Bernecker-)Lücking listed two epiphyllous records from Braulio Carrillo (1995).

Colura tortifolia (Mont.) Steph. leg. as epiphyllous by P.W.Richards at Rincon de Osa and reported by Jovet-Ast (1976), but without altitude. (Bernecker-)Lücking published one epiphyllous record from Braulio Carrillo NP (1995).

Colura verdoornii Herz. \& Jov.-Ast. Reported by (Bernecker-)Lücking as epiphyllous in the Braulio Carrillo NP (1995 and in Dauphin \& al. 1998).

Cyclolejeunea accedens (Gott.) Evans. Reported as epiphyllous by Gradstein \& al. (1994) from Monteverde at $1550 \mathrm{~m}$, and from Cerro de la Muerte road without altitude, by (Bernecker)Lücking from Braulio Carrillo NP and without altitude from Tapanti (1995, 1998).

Cyclolejeunea chitonia (Tayl.) Evans. Reported by (Bernecker-)Lücking from Braulio Carrillo NP (1995, 1998 and in Gradstein \& al. 1994) and from La Selva as epiphyllous and corticolous (1998).

Cyclolejeunea convexistipa (Lehm.\& Lindenb.) Evans. Several records without altitude and substratum reported by Herzog (1951) and Morales (1991); by Bernecker-Lücking (1995, 1998) from Braulio Carrillo NP and from further places without altitude.

Cyclolejeunea peruviana (Lehm. \& Lindenb.) Steph. Several records without altitude and substratum reported by Herzog (1951) and Morales (1991); by Bernecker-Lücking (1995, 1998) from Braulio Carrillo NP and from further places without altitude.

Diplasiolejeunea alata Jov.-Ast was reported by Morales (1994) from Tapanti and Cerro de la Muerte without altitude and substratum. The author's specimens from the Poas region from 1985 were confirmed by T.Pócs.

Diplasiolejeunea brunnea Steph. The specimens reported by Reyes (1982) and listed in Morales seem all to be epiphyllous, as Reyes does not mention different substrata. The meaning of one place "Rio Luis" is incertain, so there is remaining Santo Domingo de Golfo Dulce, without altitude. (Bernecker-)Lücking reported several epiphyllous records from Braulio Carrillo NP (1995).

Diplasiolejeunea cavifolia Steph. is pantropical, and collected in several places of Costa Rica. Reed and Robinson reported it sub $D$. brachyclada Evans from Citrus leaves in Monteverde. So its lacking in (Bernecker) Lücking's material from Braulio Carrillo is very 


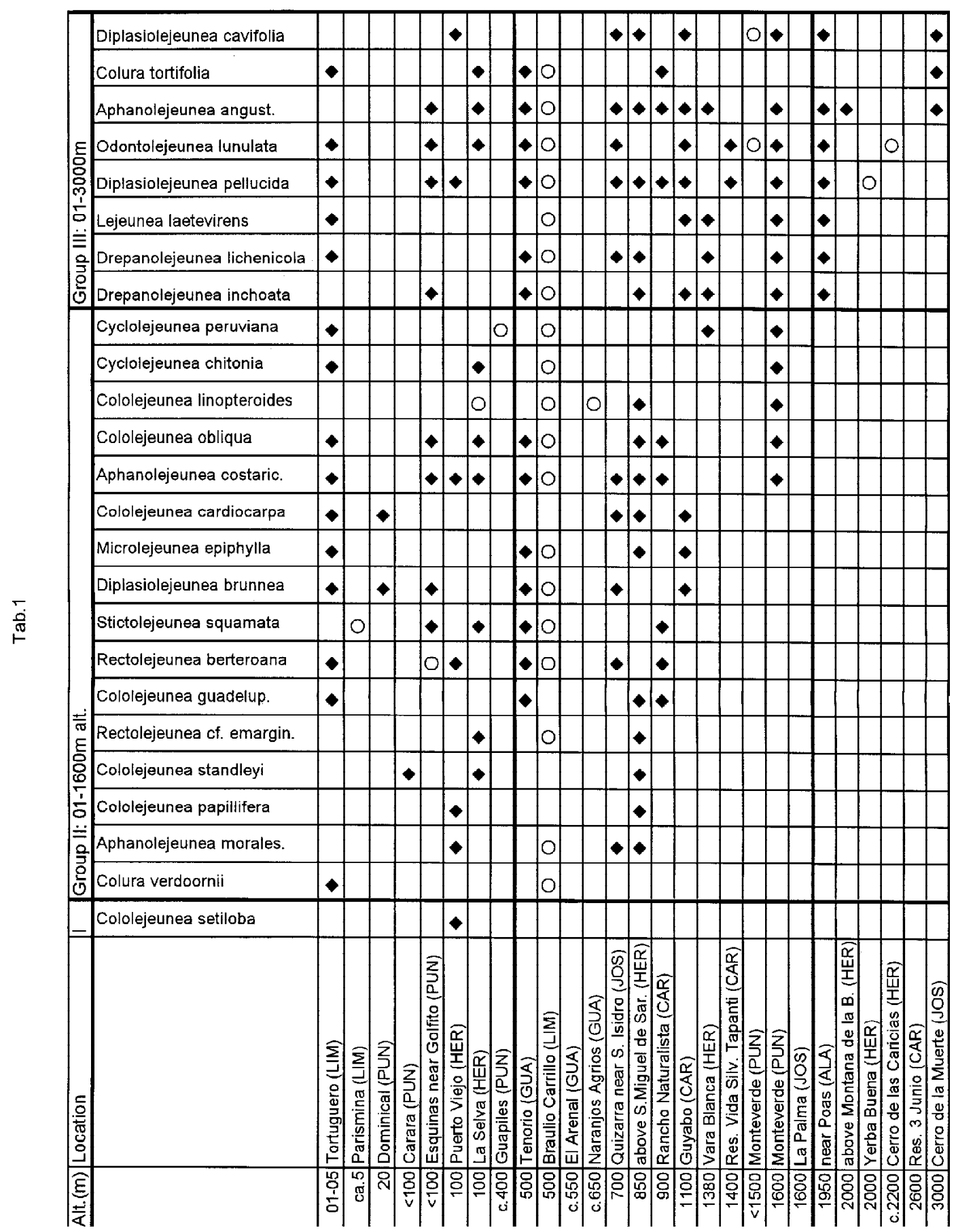




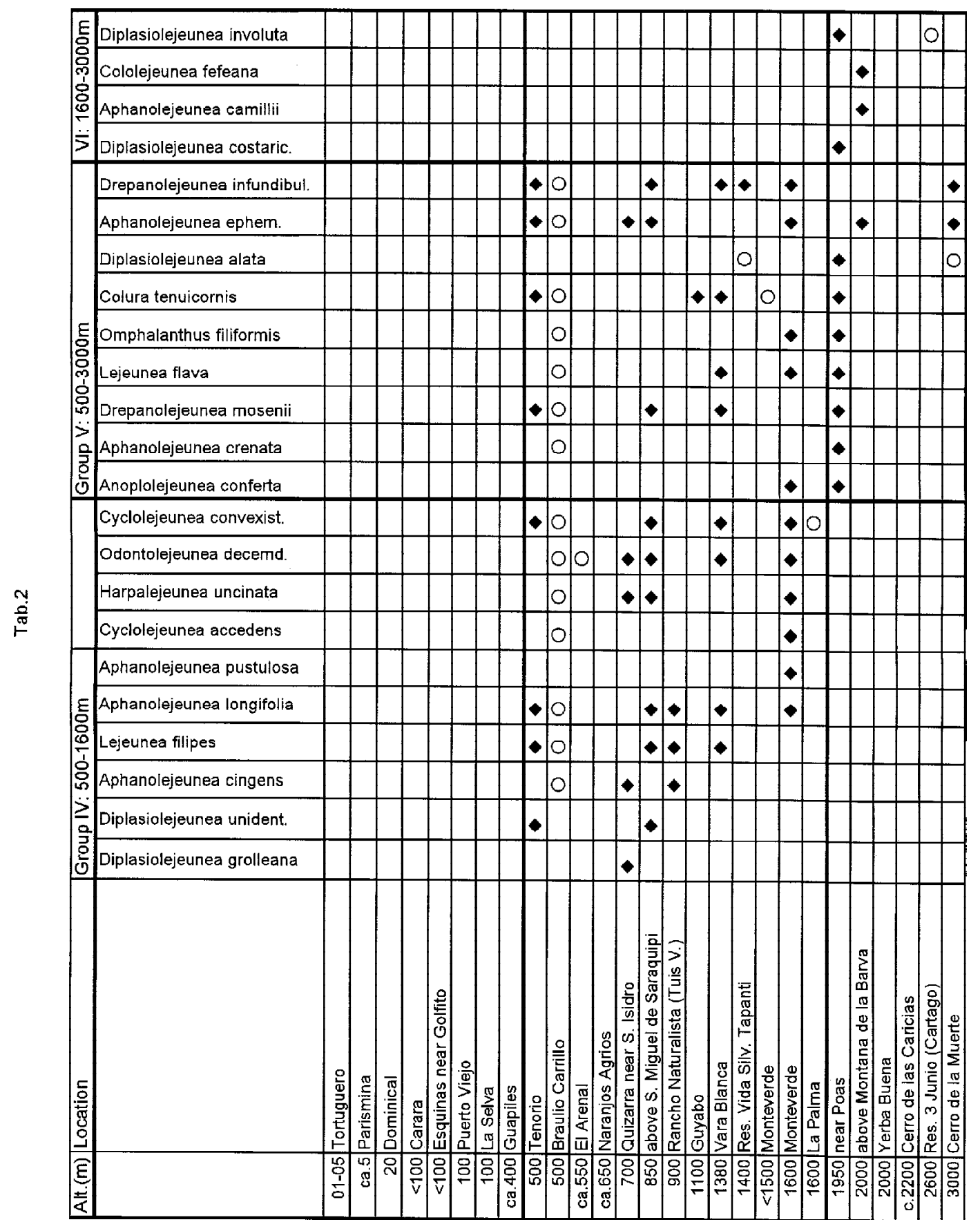

TROPICAL BRYOLOGY 20 (2001) 
astonishing (perhaps there is an identity with her D.robertiana which I have not seen).

Diplasiolejeunea costaricensis is a nomen herbariorum of a new species to describe (together with T.Pócs) in a separate paper.

Diplasiolejeunea grolleana Reyes. (See: New bryophyte taxon records ... IV, this volume).

Diplasiolejeunea involuta S.Winkler. The species was reported from San Salvador as epiphyllous at an altitude of $2350 \mathrm{~m}$ by S. Winkler (1967); in Costa Rica it was reported by Morales \& Gradstein (1995 and in Gradstein \& al. 1994) at an altitude of $2600 \mathrm{~m}$ in the Cerro de la Muerte, but epiphytic. The collections of the author in the Poas region at two places (1950m and 1970m alt.) were both epiphyllous.

Diplasiolejeunea pellucida (Meissn.) Schiffn. is reported - in the incomplete manner without substratum - from many places in Morales (1991), as epiphyllous by (Bernecker-)Lücking from Braulio Carrillo NP (1995).

Diplasiolejeunea unidentata (Lehm. \& Lindenb.) Schiffn. The only previous record from Costa Rica was epiphytic on twigs at 700m altitude, reported from Grecia in Alajuela by Dauphin \& al. (1998).

Drepanolejeunea inchoata (Meissn.) Evans also reported from many places without altitude and substratum in Herzog (1951), Bischler (1964) and again in Morales (1991). (Bernecker-)Lücking reported several epiphyllous records from Braulio Carrillo NP (1995).

Drepanolejeunea infundibulata (Spruce) Steph. (Bernecker-)Lücking reported several epiphyllous records from Braulio Carrillo NP (1995).

Drepanolejeunea lichenicola (Spruce) Steph. (Bernecker-)Lücking reported epiphyllous records from Braulio Carrillo NP (1995).

Drepanolejeunea mosenii (Steph.) Bischl. Reported by (Bernecker-)Lücking (1995 and in Gradstein \& al. 1994) from Braulio Carrillo NP. Harpalejeunea uncinata Steph. Reported by (Bernecker-)Lücking from Braulio Carrillo NP (1995 and in Dauphin \& al. 1998).

Lejeunea filipes Spruce. Described by ReinerDrehwald (2000), who regard L.autoica Schust. as probably synonymous, for Argentina as corticol. Found epiphyllous and reported sub $L$. autoica by (Bernecker-)Lücking (1995) from
Braulio Carrillo NP.

Lejeunea flava (Sw.) Nees. Reported by Herzog (1951) from Pejibaye without altitude and substratum, and by (Bernecker-)Lücking (1995) as epiphyllous from Braulio Carrillo NP.

Lejeunea laetevirens Nees \& Mont. Described by Reiner-Drehwald (2000) as only occasionally epiphyllous from Argentina. Reported by (Bernecker-)Lücking (1995) as epiphyllous for Braulio Carrillo NP.

Microlejeunea epiphylla Bischl. Reported by (Bernecker-)Lücking (1995 and in Gradstein \& al. 1994) from Braulio Carrillo NP and from the Osa Pensinsula at $300 \mathrm{~m}$ growing on tree trunk. Odontolejeunea decemdentata (Spruce) Steph. Teeuwen in his monograph (1989) pointed that the species is epiphyllous, sometimes on twigs, and reported it from several localities in Costa Rica without altitude, as did Morales (1991) without altitude and substratum. (Bernecker)Lücking mentioned it as the most frequent epiphyllous member of the genus in the Braulio Carrillo NP (1995).

Odontolejeunea lunulata (Web.) Schiffn. This species is reported by Teeuwen (1989) as epiphyllous, occasionally on twigs o rarely on soil. The specimens listed by him lack substratum information, but mostly contain altitude; if epiphyllous there may be added several places to our table (1, group III) but without changing the result. Several records are liste in (Bernecker)Lücking for Braulio Carrillo NP (1995).

Omphalanthus filiformis (Sw.) Nees, which is growing epiphytic and epiphyllous, was reported by (Bernecker-)Lücking (1995) from Braulio Carrillo NP.

Rectolejeunea berteroana (Gott.) Evans. Without substratum and altitude reported by Morales (1991) from Golfo Dulce; by (BerneckerLücking (1995) epiphyllous for Braulio Carrillo NP and for Golfito.

Rectolejeunea cf. emarginuliflora (Gott.) Evans. Reported for Braulio Carrillo NP by (Bernecker)Lücking (1995).

Stictolejeunea squamata (Willd. ex Web.) Schiffn. This species is more often epiphytic than epiphyllous and sometimes even saxicolous (Gradstein 1985); he further mentioned that he never found reproductive organs in the epiphyllous specimens, but (Bernecker-)Lücking 
reported fertile epiphyllous plants from Braulio Carrillo NP. In the author's material the collection from Tenorio contains male plants.

\section{Acknowledgements}

I wish to thank Prof. Dr. T. Pócs (Eger, Hungary) for determination and/or confirmation of critical species.

\section{References}

(Bernecker-)Lücking, A. 1995. Diversität und Mikrohabitatpräferenzen epiphyller Moose in einem tropischen Regenwald in Costa Rica unter besonderer Berücksichtigung der Lejeuneaceae. Diss. Ulm. 211pp.

Bernecker-Lücking, A. 1998a. New species of Lejeuneaceae (Hepaticae) from Costa Rica. 1. Aphanolejeunea. Nova Hedwigia 66 (12): 163-172.

Bernecker-Lücking, A. 1998b. The genus Cyclolejeunea A. Evans (Hepaticae, Lejeuneaceae) in Costa Rica. Phyton 38 (1): 175-193.

Bernecker-Lücking, A. \& Morales Z., M.I. 1999. Notes and additions to Cololejeunea linopteroides with special reference to Cololejeunea sigmoidea (Hepaticae, Lejeuneaceae). The Bryologist 102 (3): 437 441.

Dauphin, G., Gradstein, S.R., Bernecker-Lücking, A. \& Morales, M.I. 1998. Additions to the hepatic flora of Costa Rica II. Lindbergia 23: 74-80.

Equihua, C. \& Pócs, T. 2000.Epiphyllous bryophytes from the Lacandon Forest, Chiapas, Mexico. The Bryologist 102 (4): 747-752, "1999".

Gradstein, S.R. 1985. A revision of the genus Stictolejeunea (Spruce) Schiffn. in: Gradstein (ed.), Contributions to a monograph of the Lejeuneaceae Subfamily
Ptychanthoideae. Beihefte zur Nova Hedwigia 80: 195-219.

Gradstein, S.R., Lücking, A., Morales Z., M.I. \& Dauphin, G. 1994. Additions to the hepatic flora of Costa Rica. Lindbergia 19: 73-86.

Gradstein, S.R. \& Frahm, J.-P. 1987.Die floristische Höhengliederung der Moose entlang des BRYOTROP-Transektes in NO-Peru. In: Frey, W. (ed.) Moosflora und -vegetation in Regenwäldern NO-Perus. Beihefte zur Nova Hedwigia 88: 105-113.

Herzog, T. 1951. Hepaticae Standleyanae Costaricenses et Hondurenses. Pars II. Revue bryologique et lichénologique 20: 126-175.

Jovet-Ast, S. 1976. Compléments à la connaissance des Colura: espèces et localités nouvelles. Revue bryologique et lichénologique 42: 909-922.

Morales Z., M.I. 1991.Las hepaticas communicadas para Costa Rica. Tropical Bryology 4: 2557.

Morales Z., M.I. \& Gradstein, S.R. 1995. Diplasiolejeunea involuta Winkler una especie poco conocida. Tropical Bryology 10: 75-79.

Reiner-Drehwald, E. 2000. Las Lejeuneaceae (Hepaticae) de Misiones, Argentina. VI. Lejeunea y Taxilejeunea. Tropical Bryology 19: 81-131.

Reyes, D.M. 1982. El genero Diplasiolejeunea en Cuba. Acta Botanica Academiae Scientiarum Hungariae 28 (1-2): 145-180.

Robinson, H. 1964. New taxa and new records of bryophytes from Mexico and Central America. The Bryologist 67: 456-457.

Teeuwen, M. 1989. A revision of the genus Odontolejeunea (Spruce) Schiffn. (Lejeuneaceae, Hepaticae). Nova Hedwigia 48 (1-2): 1-32.

Winkler, S. 1967. Die epiphyllen Moose der Nebelwälder von El Salvador, C.A. Revue bryologique et lichénologique 35: 303-369. 
